\title{
An autophagosome-based therapeutic vaccine for HBV infection: a preclinical evaluation
}

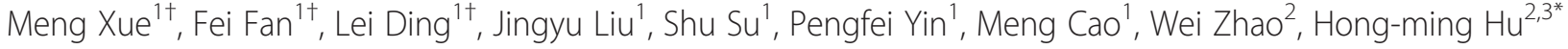 \\ and Lixin Wang ${ }^{1,2^{*}}$
}

\begin{abstract}
Background: For more than 240 million chronic HBV carriers worldwide, effective therapeutic HBV vaccines are urgently needed. Recently, we demonstrated that autophagosomes were efficient antigens carriers and capable to cross-prime robust T-cell responses and mediate regression of multiple established tumors. Here we tested whether autophagosomes derived from HBV expressing cells could also function as a therapeutic vaccine.

Methods: We generated an autophagosome-based HBV vaccine from HBV-expressing hepatoma cells and examined its ability to induce polyvalent anti-HBV T-cell responses and therapeutic efficacy in mouse models that mimic acute and chronic HBV infection in human.

Results: When compared to the vaccine based on recombinant HBsAg, autophagosome-based HBV vaccine cross-primed multi-specific anti-HBV T-cell responses and significantly reduced HBV replication and HBCAg expression in livers of both acute and chronic mouse models. Therapeutic effect of this HBV vaccine depended on anti-HBV $\mathrm{CD}^{+}$effector T cells and associated with increased HBsAg and HBCAg specific IFN- $\gamma$ producing $T$ cells in the chronic mouse model.

Conclusions: These results indicated that autophagosome-based HBV vaccine could effectively suppress the HBV replication, clear the HBV infected hepatocytes, and break the HBV tolerance in mouse model. The potential clinical application of autophagosome-based HBV vaccine is discussed.
\end{abstract}

Keywords: Hepatitis B virus, DRibbles, Therapeutic vaccine, Autophagy

\section{Background}

Chronic hepatitis B virus (HBV) infection remains a major health problem worldwide as it often causes many serious complications like hepatic cirrhosis and hepatocellular carcinoma [1]. The current treatment for chronic HBV infection is primarily based on antiviral chemotherapy or interferon therapy. Although these agents have improved considerably over the last 10 years, they fail to eradicate infection due to the persistence of HBV covalently closed circular DNA (cccDNA) in hepatocytes and the emergence of resistant viruses [2-5].

\footnotetext{
* Correspondence: hhu@providence.org; lxwang@seu.edu.cn

${ }^{\dagger}$ Equal contributors

${ }^{2}$ Cancer Research and Biotherapy Center, the Second Affiliated Hospital of Southeast University, Nanjing, Jiangsu, PR China

'Department of Microbiology and Immunology, Medical School of Southeast University, Nanjing, Jiangsu, PR China

Full list of author information is available at the end of the article
}

Therapeutic vaccination is a promising strategy to control chronic infection and delay the progression of diseases, especially when used in combination with antivial chemotherapy. Unfortunately, therapeutic vaccination of chronic HBV patients with HBsAg in combination with antiviral chemotherapy did not show any superior efficacy over chemotherapy alone [6]. Attempt to increase the therapeutic efficacy using HBsAg combined with anti-HBs immunoglobulin only showed a minor improvement [7]. Similarly, a vaccination strategy using DNA prime and protein boost also worked poorly in a recent randomized clinical trial [8]. These rather disappointing results are likely related to the fact that vaccination with the HBsAg alone is insufficient and a strong, polyvalent, and poly-functional $\mathrm{CD} 8^{+} \mathrm{T}$-cell response against other $\mathrm{HBV}$ antigen besides HBsAg is required for viral clearance. Such a T-cell response was detected in subjects with self-limited HBV infection, but it is exhausted and 
functionally impaired in patients with chronic HBV infection [9]. Thus, novel therapeutic vaccines are urgently needed for the treatment of chronic HBV infection [10]. Based on our current knowledge, an ideal HBV therapeutic vaccine needs to be able to elicit a strong and multi-specific $\mathrm{T}$ cell response, which is capable of controlling HBV infection [11].

Recently, others and we have shown that autophagy of tumor cells or virus-infected cells plays important roles for the efficient cross-presentation of tumor and viral antigens [12-16]. However, cross-presentation favors abundant proteins with a long half-life and largely ignores short-lived proteins. The efficiency of cross-presentation of short-lived proteins could be greatly increased by inducing autophagy via inhibition of proteasome-mediated proteolysis. Consequently, autophagosomes containing short-lived defective ribosomal products (DRiPs), which we referred to as DRibbles, were found to be highly effective therapeutic cancer vaccines in multiple mouse cancer models [13-16]. Thus, it is generally accepted that autophagy can promote both MHC class II and class I restricted T-cell immune responses to either tumors or infectious pathogens [12-16].

Based on above findings, we hypothesized that increased autophagy of HBV expressing hepatoma cells [17] could enhance the sequestration of multiple HBV antigens into autophagosomes. These isolated autophagosome $\left(\mathrm{HBV}^{+}\right.$DRibbles) can serve as a potent vaccine to stimulate polyvalent $\mathrm{HBV}$-specific T-cell responses. To test this hypothesis, we examined whether different autophagy inducers could increase the production of DRibbles from a HBV-producing hepatoma cells and further investigated whether $\mathrm{HBV}^{+}$DRibbles vaccine could induce polyvalent anti-HBV immune responses and reduce 'HBV infection' in a mouse model [18].

\section{Materials and methods Ethics statement}

All experimental protocols were approved by the Institutional Animal Care and Use Committee of Southeast University.

\section{Mice, cell lines and reagents}

C57BL/6 female mice were purchased from the Comparative Medicine Center, Yangzhou University. All mice were bred and maintained in specific pathogen-free conditions. HepG2.2.15 and HepG2 cell lines were gifts from Dr. Jianqiong Zhang (Medical School of Southeast University, China). All the cells were cultured in complete medium made of DMEM or RPMI 1640 (Gibco, USA) supplemented with 10\% heat-inactivated FCS (Hyclone, USA), $100 \mathrm{U} / \mathrm{ml}$ penicillin, $0.1 \mathrm{mg} / \mathrm{ml}$ streptomycin (Beyotime Institute of Biotechnology, China).

\section{HBV infection model}

Naïve C57BL/6 mice (female, 6-8 weeks old) were injected with $10 \mu \mathrm{g}$ of pAAV/HBV1.2 plasmid DNA (containing the HBV full-length genomic DNA) via the hydrodynamic injection as described [18].

\section{Preparation of $\mathrm{HBV}^{+}$DRibbles or $\mathrm{HBV}^{-}$DRibbles}

HepG2.2.15 cells containing transfected HBV full-length DNA [17] or HepG2 cells were treated with $200 \mathrm{nmol} / \mathrm{L}$ Bortizomib (Millennium pharmaceuticals, USA) alone or in combination with $100 \mathrm{nmol} / \mathrm{L}$ Rapamycin (Enzo Life Sciences, China) or $30 \mathrm{mmol} / \mathrm{L} \mathrm{NH}_{4} \mathrm{Cl}$ for $18 \mathrm{~h}$, DRibbles containing autophagosomes were prepared from the culture media as described [13,14]. Morphology analysis of $\mathrm{HBV}^{+}$DRibbles was done under transmission electron microscopy. HBsAg in HepG2.2.15 cell lysates was detected by western blot analysis using anti-HBsAg antibody (Santa Cruz, Biotechnology, Inc., USA). LC3 in both HepG2.2.15 cell lysates and $\mathrm{HBV}^{+}$DRibbles was determined by western blot analysis using the polyclonal LC3B antibody (Cell Signal Technology, USA,1:1000), the HRP-labeled goat anti-rabbit IgG secondary antibody (1:5000) and a chemiluminescence kit (Multisciences Biotech Co., Ltd., China). Levels of HBsAg and HBeAg in $\mathrm{HBV}^{+}$DRibbles were measured by ELISA (Shanghai Kehua Bioengineering Co., Ltd., China).

\section{Measurement of immune responses induced by vaccination with $\mathrm{HBV}^{+}$DRibbles}

C57BL/6 mice were immunized with different doses of $\mathrm{HBV}^{+}$DRibbles or $\mathrm{HBV}^{-}$DRibbles $(100,30,10 \mu \mathrm{g}$ total protein per mouse) or PBS via intranodal injection. Seven days later, $2 \times 10^{5}$ lymphocytes per well were harvested and re-stimulated with HBV antigens or peptides (HBc129-140: PPAYRPPNAPIL; HBs190-197: VWLSVIWM) (ChinaPeptides Co., Ltd., China) for $24 \mathrm{~h}$. The number of IFN- $\gamma$ producing cells was detected by ELISPOT assay (Laizee Biotech Co., Ltd., China).

To determine whether $\mathrm{HBV}^{+}$DRibbles elicited cell response and killed HBV infected hepatocytes, lymphocytes were harvested from $\mathrm{HBV}^{+}$DRibbles vaccinated mice at day 7 and used as effector T cells; hepatocytes were collected from mice injected with pAAV/HBV1.2 plasmid DNA as the HBV-expressing target cells. Lymphocytes $\left(2 \times 10^{6} /\right.$ well $)$ were co-incubated with target cells $\left(2 \times 10^{4} /\right.$ well $)$. The supernatants were collected for detection of AST by clinical chemistry analyzer after $24 \mathrm{~h}$ or for detection of IFN- $\gamma$ by ELISA (eBioscience, USA) after $72 \mathrm{~h}$.

\section{Anti-HBV effect of vaccination with $\mathrm{HBV}^{+}$DRibbles}

C57BL/6 mice were immunized with $\mathrm{HBV}^{+}$DRibbles, $\mathrm{HBV}^{-}$DRibbles or PBS via intranodal injection as described above. Seven days later, $10 \mu \mathrm{g}$ of pAAV/HBV1.2 plasmid 
DNA was injected via tail vein [18]. Serum samples were collected at day 14 for detection of HBeAg by ELISA and HBV genomic DNA with real-time PCR. Liver tissues were collected and embedded in paraffin. Intracellular $\mathrm{HBcAg}$ expression was detected by immunohistochemical staining with the rabbit anti-HBcAg antibody (1:100) using two-step method (Zhongshan Goldenbridge Biotechnology Co., Ltd., China). Percentages of $\mathrm{HBcAg}^{+}$hepatocytes were calculated by counting at least 500 cells in five vision fields by two investigators for each sample.

\section{Depletion of $\mathrm{CD}^{+}$and $\mathrm{CD}^{+}{ }^{+} \mathrm{T}$ cell subsets in vivo}

Mice were vaccinated with $30 \mu \mathrm{g} \mathrm{HBV}{ }^{+}$DRibbles or PBS as above mentioned. On day 7, after injection of pAAV/ HBV1.2 DNA into the mice, $200 \mu \mathrm{g}$ anti-CD4 mAb (clone GK1.5, rat IgG2b) or/and $20 \mu \mathrm{g}$ anti-CD8 $\mathrm{mAb}$ (clone 2.43, rat IgG2b) were administered intraperitoneally, and the depleted condition was maintained by repeated injections of the monoclonal antibody every 3 days for total of 3 injections. At day 14, HBeAg level and HBV DNA copy number in the serum samples and intrahepatic $\mathrm{HBcAg}$ expression in liver tissues were detected as described above.

\section{Therapeutic vaccination experiments}

C57BL/6 mice were injected hydrodynamically with pAAV/HBV1.2 plasmid DNA and were vaccinated with $30 \mu \mathrm{g} \mathrm{HBV}{ }^{+}$DRibbles, $2 \mu \mathrm{g}$ HBsAg with $\mathrm{Al}(\mathrm{OH})_{3}$ adjuvant (Center for Disease Control of Jiangsu Province, China) or PBS via intranodal injection 2 days later. Then, two intramuscular boost injections $(2 \mu \mathrm{g}$ of $\mathrm{HBsAg}$ with $\mathrm{Al}$ $(\mathrm{OH})_{3}$ adjuvant or $30 \mu \mathrm{g}$ of $\mathrm{HBV}^{+}$DRibbles with $\alpha \mathrm{Al}_{2} \mathrm{O}_{3}$ nanoparticles adjuvant [19]) were performed on day 5 and 7 . The lymphocytes were isolated 7 days after first vaccination and re-stimulated with recombinant $\mathrm{HBV}$ antigens and peptides as described. The number of IFN- $\gamma$ producing cells in $2 \times 10^{5}$ lymphocytes was detected by ELISPOT. The serum samples were collected on day 7 and 14 after first vaccination for measurement of ALT, AST, HBeAg , HBsAg, HBV DNA. The serum anti-HBsAg antibodies were detected by ELISA on day 14 after first vaccination. Liver tissues were collected on day 14 after first immunization for detection of percentage of $\mathrm{HBcAg}^{+}$ hepatocytes as mentioned above. The liver sections were stained with hematoxylin-eosin.

\section{Adoptive transfer experiments}

C57BL/6 mice were injected hydrodynamically with $10 \mu \mathrm{g}$ pAAV/HBV1.2 plasmid DNA to establish HBV tolerant mice [18]. Sixty days later, tolerance toward HBsAg was noted in HBV carrier mice. The HBsAg tolerant mice were selected and then immunized with above $\mathrm{HBV}^{+}$DRibbles or HBsAg or PBS on day 61, respectively. Two intramuscular boost injections with the same dose of vaccines as above were done on day 63 and 65. Lymphocytes were harvested from the immunized mice and re-stimulated with HBV antigens and peptides on day 67 as described. The number of IFN- $\gamma$ producing cells in $2 \times 10^{5}$ lymphocytes was measured by ELISPOT. In addition, at day 68, a total of $1 \times 10^{8}$ lymphocytes from vaccinated HBsAg tolerant mice were adoptive transferred intravenously into each of the new set of 60-day HBV carrier mice. Serum samples were collected on day 3, 7, 14 and 21 after adoptive transfer for detection of ALT, AST, HBsAg and HBV DNA. The serum anti-HBsAg antibodies were measured by ELISA on day 21 after adoptive transfer. Liver tissues were collected on day 21 for detection of percentage of $\mathrm{HBcAg}^{+}$hepatocytes. The liver sections were stained with hematoxylin-eosin.

\section{Statistical analysis}

One-way ANOVA or two-way ANOVN with Bonferronic post test and the two-tails paired $t$ test were performed using GraphPad Prism5.0, (GraphPad Software Inc., San Diego, CA). A $P$ value of $<0.05$ was considered statistically significant.

\section{Results}

DRibbles are capable to encapsulate multiple HBV antigens First, we investigated whether DRibbles contained HBV antigens when they were prepared from HepG2.2.15 cells that were transfected with HBV DNA and stably expressed HBV antigens. HepG2.2.15 cells were treated with Bortizomib, Rapamycin or $\mathrm{NH}_{4} \mathrm{Cl}$ at the predetermined optimal concentrations; whole cell lysates and DRibbles were prepared as described and subjected to western blot analysis using antibodies against $\mathrm{HBsAg}$ and LC3 [13]. The major HBsAg protein did not differ after different treatments (Figure 1A). Interestingly, Bortizomib treatment led to appearance of HBsAg of lower molecular weight than full-length products and addition of $\mathrm{NH}_{4} \mathrm{Cl}$ further increased the appearance of these bands (Figure 1A). Because these bands appear only after inhibition of proteasome function, they are most likely representatives of DRiPs of HBsAg. No significant conversion of LC3 protein was found in HepG2.2.15 cells treated with Bortizomib, Rapamycin, or combination of both. However, accumulation of LC3-II in cell lysates and predominant LC3-II in the DRibbles was found when $\mathrm{NH}_{4} \mathrm{Cl}$ was included in addition to Bortizomib and Rapamycin treatment (Figure 1B,C) [20,21]. Transmission electron microscopy analysis showed that DRibbles had a double-membrane structure and their size was ranged from 100 to $1000 \mathrm{~nm}$ (Figure 1D). ELISA analysis showed that the amount of HBsAg and $\mathrm{HBeAg}$ in the DRibbles were doubled when all three drugs were combined (Figure 1E,F). These data indicated that combination of Bortizomib, Rapamycin, and 


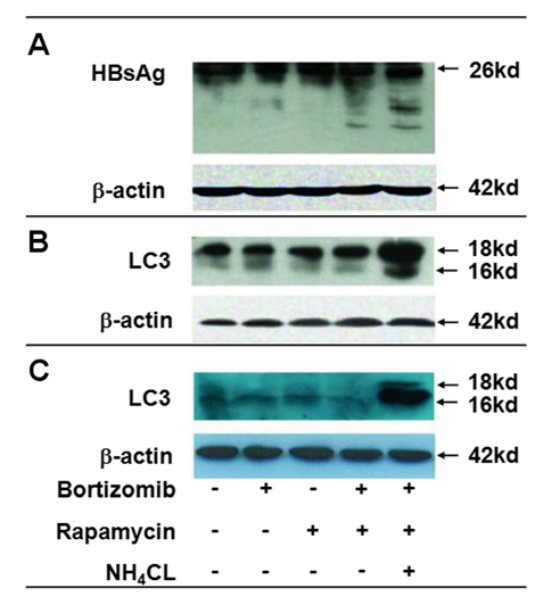

D

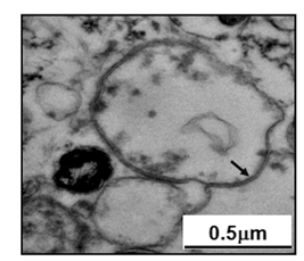

E

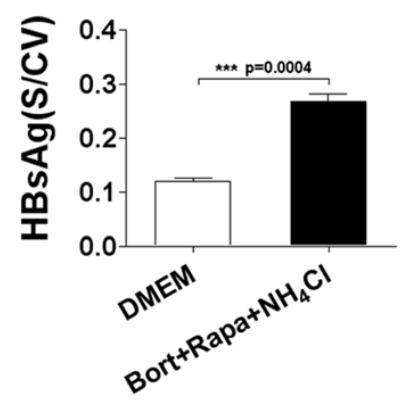

$\mathbf{F}$

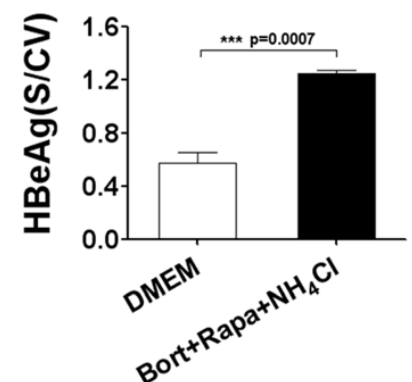

Figure 1 Detection of HBV antigens in DRibbles. HepG2.2.15 cells were treated without (lane 1) or with Bortizomib alone (lane 2), Rapamycin alone (lane 3), Bortizomib plus Rapamycin (lane 4) or combination of Bortizomib, Rapamycin and $\mathrm{NH}_{4} \mathrm{Cl}$ (lane 5) for 18 h. Lysates were prepared for the HBsAg and the LC3 conversion analysis by western blot $(\mathbf{A}, \mathbf{B})$. The HBV ${ }^{+}$DRibbles prepared from both untreated and treated cells were analyzed for LC-3-I and LC-3-II by western blot analysis (C). Anti- $\beta$-actin antibody was included as a sample loading control. Morphology of DRibbles was observed by transmission electron microscopy (D). The amount of HBeAg (E) and HBsAg (F) in the DRibbles were quantified by ELISA.

$\mathrm{NH}_{4} \mathrm{Cl}$ could induce efficient sequestration of both $\mathrm{HBsAg}$ and HBeAg into autophagosomes.

\section{$\mathrm{HBV}^{+}$DRibbles elicit protective HBV-specific immune responses}

To determine the optimal dose of $\mathrm{HBV}^{+}$DRibbles to elicit HBV antigen-specific immune responses, different doses of $\mathrm{HBV}^{+}$DRibbles or $\mathrm{HBV}^{-}$DRibbles were administrated into the lymph nodes of naive C57BL/6 mice (Figure 2A). We chose the intranodal injection of DRibbles as the route of antigen delivery because our preliminary experiments indicated direct injection of DRibbles into lymph nodes resulted the greatest DCs recruitment and T-cell activation. ELISPOT assay revealed that spleen and lymph nodes from mice injected with $30 \mu \mathrm{g}$ of $\mathrm{HBV}^{+}$DRibbles contained the highest number of $\mathrm{HBsAg}$ or $\mathrm{HBcAg}$ specific IFN- $\gamma$ producing cells (Figure 2B). Injection of $10 \mu \mathrm{g}$ of DRibbles was insufficient, while $100 \mu \mathrm{g}$ showed a high-dose suppression. To further determine whether immunogenicity and xenoreaction of DRibbles derived from human HepG2 cells ( $\mathrm{HBV}^{-}$DRibbles) lead to immune reactive to $\mathrm{HBV}$ antigens, $\mathrm{C} 57 \mathrm{BL} / 6$ mice were also immunized with titrated amount of $\mathrm{HBV}^{-}$DRibbles. Noticeably, lymphocytes from $30 \mu \mathrm{g} \mathrm{HBV}^{+}$DRibbles vaccinated mice generated much higher number of IFN- $\gamma$ producing cells than that from $30 \mu \mathrm{g} \mathrm{HBV}{ }^{-}$DRibbles vaccinated mice when re-stimulated with either $\mathrm{HBV}$ antigens or HBV peptides (Figure 2C). Thus, $\mathrm{HBV}^{+}$DRibbles effectively induced both HBsAg- and HBcAg-specific and $\mathrm{HBc}_{129-140}$, $\mathrm{HBs}_{190-197^{-}}$ specific cell-mediated immune responses. Thirty $\mu \mathrm{g}$ total proteins seem to be optimal dose for the $\mathrm{HBV}^{+}$DRibbles vaccine administrated via intranodal injection in mice.

To evaluate whether $30 \mu \mathrm{g}$ of $\mathrm{HBV}^{+}$DRibbles could protect immunized mice from establishment of $\mathrm{HBV}$ replication via $\mathrm{HBV}$ plasmid DNA injection, C57BL/6 mice were vaccinated with PBS or different doses of $\mathrm{HBV}^{+}$DRibbles or $\mathrm{HBV}^{-}$DRibbles and were challenged with hydrodynamic injection of HBV DNA 7 days later (Figure 2A). Serum HBV DNA and HBeAg levels were used as the indicators of viral replication and production. Mice immunized with $30 \mu \mathrm{g} \mathrm{HBV}^{+}$DRibbles, but not naïve mice or mice immunized with $\mathrm{HBV}^{-}$DRibbles and other doses of $\mathrm{HBV}^{+}$DRibbles, were protected from $\mathrm{HBV}$ DNA challenge (Figure 2D,E). To further corroborate this data, liver tissues were harvested and intrahepatic expressing of $\mathrm{HBcAg}$ was quantified by immunohistochemical staining. Similar to the results of HBeAg and HBV DNA, the percentage of $\mathrm{HBcAg}^{+}$hepatocytes in the mice 
A

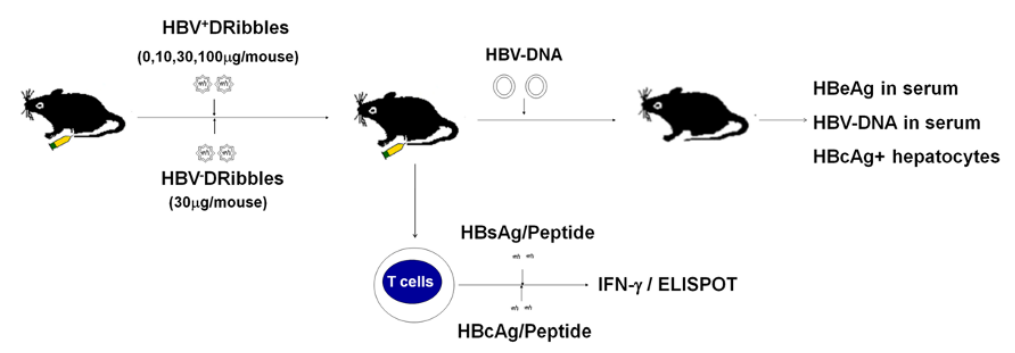

B

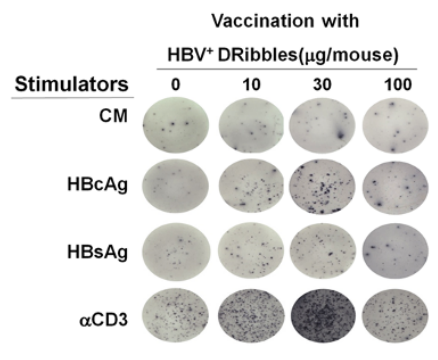

C

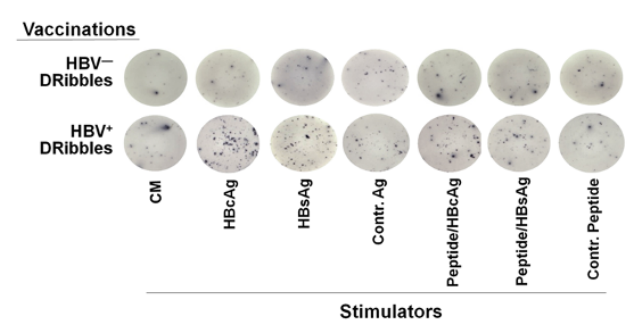

D

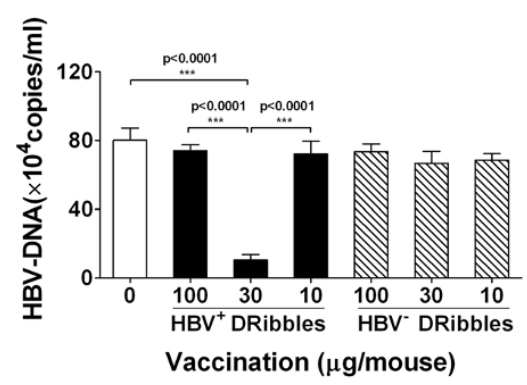

$\mathrm{F}$

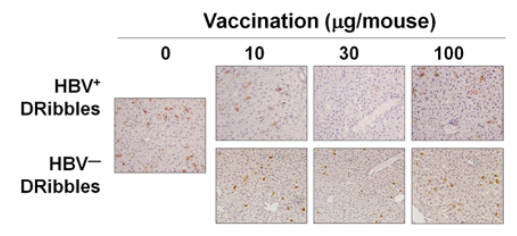

Stimulators

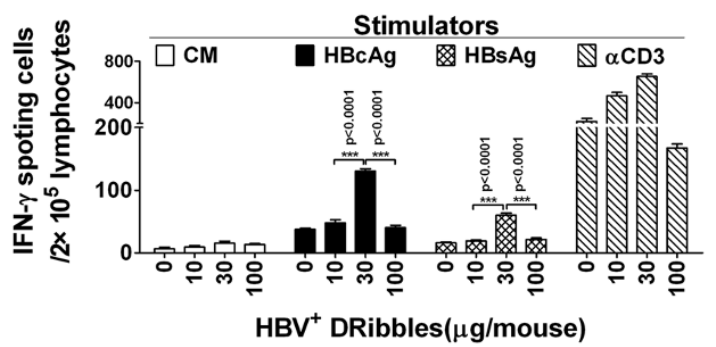

$\mathrm{HBV}^{+}$DRibbles( $\mu \mathrm{g} /$ mouse)

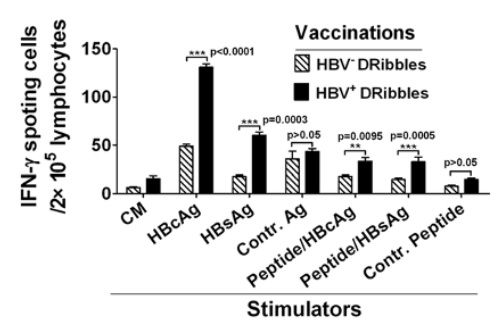

E
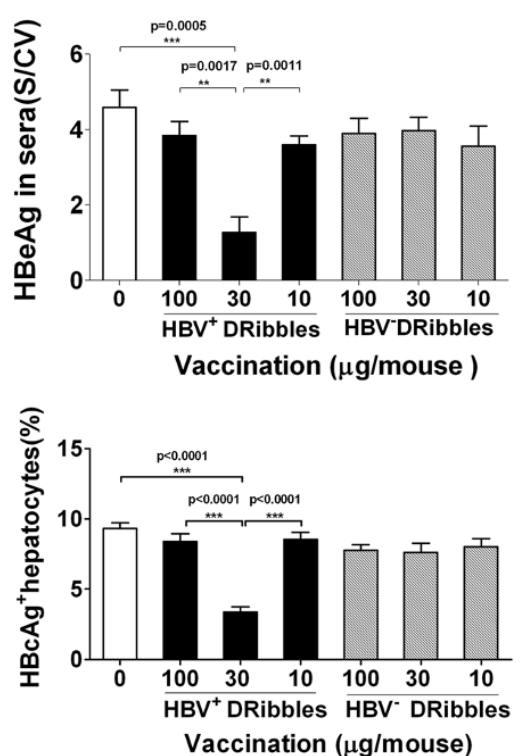

Figure $\mathbf{2} \mathrm{HBV}^{+}$DRibbles elicited HBV-specific protective immune response. The schematic diagram outlines the experiment protocol (A). The optimal dose of $\mathrm{HBV}^{+}$DRibbles was determined by ELISPOT assay $(n=3)$. Lymphocytes from mice received $\mathrm{HBV}^{+}$DRibbles generated a high number of IFN- $\gamma$ secreting cells in $2 \times 10^{5}$ lymphocytes $(\mathbf{B}, \mathbf{C})$. Vaccinated mice were injected hydrodynamically with $10 \mu \mathrm{g}$ of HBV plasmid DNA $(n=5) 7$ days later. The serum HBV DNA (D) and HBeAg (E) was determined by real-time PCR and ELISA. Intrahepatic HBCAg was visualized by immunohistochemical staining $(\times 200)(\mathbf{F})$. Results represent three independent experiments. 
immunized with $30 \mu \mathrm{g} \mathrm{HBV}^{+}$DRibbles was significantly lower than control mice injected with $\mathrm{HBV}^{-}$DRibbles or PBS (Figure 2F). Moreover, there were no significant difference between the mice immunized with $\mathrm{HBV}^{-}$DRibbles and those with PBS. Our results showed that $\mathrm{HBV}^{+}$ DRibbles vaccination, but not $\mathrm{HBV}^{-}$DRibbles, could effectively reduce HBV replication and expression.

\section{$\mathrm{CD}^{+} \mathrm{T}$ cells induced by $\mathrm{HBV}^{+}$DRibbles mediated suppression of HBV replication}

To investigate the requirement of $\mathrm{CD} 4^{+}$helper $\mathrm{T}$ cells or $\mathrm{CD}^{+}$effector $\mathrm{T}$ cells for the control of $\mathrm{HBV}$ replication, anti-CD4 $\mathrm{mAb}$ or/and anti-CD8 $\mathrm{mAb}$ were administrated intraperitoneally on the same day as HBV DNA injection into $\mathrm{HBV}^{+}$DRibbles-vaccinated mice. The monoclonal antibodies were injected repeatedly every 3 days to maintain the depleted condition (Figure 3A). Results showed again that non-depleted mice immunized with $\mathrm{HBV}^{+}$DRibbles had a reduced level of serum $\mathrm{HBeAg}$ (Figure 3B), DNA copy number (Figure $3 \mathrm{C}$ ) and $\mathrm{HBcAg}^{+}$ expressing hepatocytes (Figure 3D). The DNA copy number in mice depleted of $\mathrm{CD}_{8}{ }^{+}$effector $\mathrm{T}$ cells were not significantly different from that of control non-immunized naïve mice. Depletion of both $\mathrm{CD} 4^{+}$and $\mathrm{CD} 8^{+}$effector $\mathrm{T}$ cells did not further increase the serum HBeAg or DNA copy number beyond that of mice received anti-CD8 antibody (Figure 3B,C). These data indicated the critical requirement for priming of anti-HBV $\mathrm{CD}^{+} \mathrm{T}$ cells for viral clearance.

To examine the effect function of $\mathrm{T}$ cells from $\mathrm{HBV}^{+}$ DRibbles vaccinated mice, lymphocytes from $\mathrm{HBV}^{+}$DRibbles immunized mice were co-cultured with hepatocytes isolated from HBV DNA injected mice (Figure 3A). Results showed that significantly higher levels of IFN- $\gamma$ were detected in the culture supernatants when effector $T$ cells were incubated with HBV-expressing hepatocytes than control hepatocytes (Figure 3E). Moreover, AST detection showed that significantly higher levels of AST enzyme release were found in HBV-expressing hepatocytes than control hepatocytes (Figure 3F). These data suggested that $\mathrm{HBV}^{+}$DRibbles elicited strong cell immune response that was capable to produce IFN- $\gamma$ and kill $\mathrm{HBV}$-expressing hepatocytes isolated from mice in vitro.

\section{Vaccination with $\mathrm{HBV}^{+}$DRibbles was effective against acute $\mathrm{HBV}$ infection}

To test whether $\mathrm{HBV}^{+}$DRibbles could be used as therapeutic vaccine in a setting that mimicking acute $\mathrm{HBV}$ infection and to compare the efficacy of $\mathrm{HBV}^{+}$DRibbles with recombinant protein $\mathrm{HBsAg}$ vaccine, $\mathrm{C} 57 \mathrm{BL} / 6$ mice were first injected with pAAV/HBV1.2 DNA to establish $\mathrm{HBV}$ acute infection and then were immunized with $\mathrm{HBV}^{+}$ DRibbles or HBsAg or PBS 2 days later. Two times boost immunizations were administrated by intramuscular

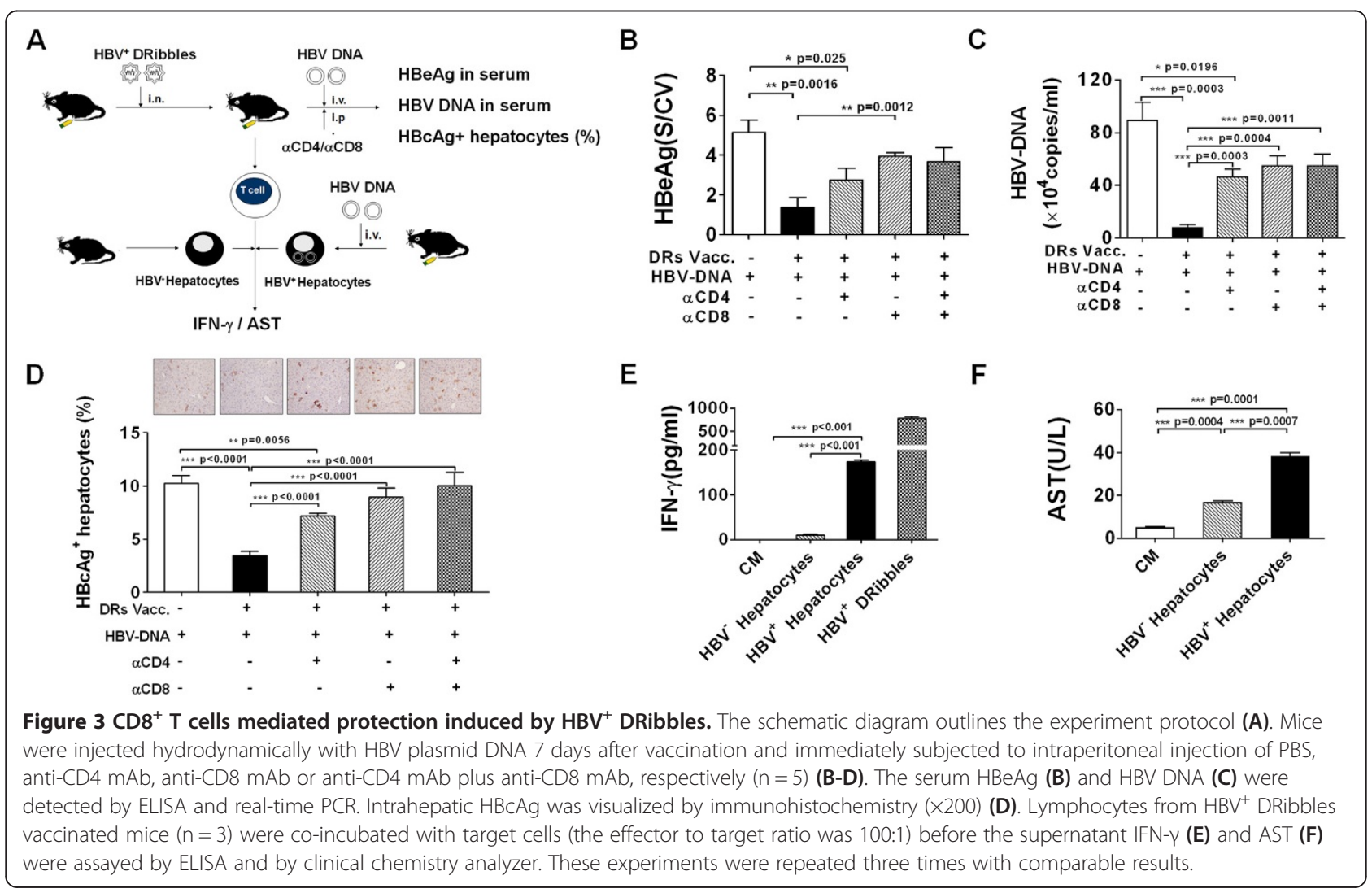


injection every 2 days. Here, $\alpha-\mathrm{Al}_{2} \mathrm{O}_{3}$ nanoparticles adjuvant was used in our $\mathrm{HBV}^{+}$DRibbles vaccine due to its ability to greatly increase the efficiency of crosspresentation and anti-tumor response of cancer vaccines [19] (Figure 4A).

Consistent with previous results, lymphocytes harvested from $\mathrm{HBV}^{+}$DRibbles-immunized mice generated a significantly higher number of IFN- $\gamma$ producing cells than that from PBS or HBsAg immunized mice when re-stimulation ex vivo with $\mathrm{HBV}$ antigens or peptides (Figure 4B,C,D). The serum levels of $\mathrm{HBeAg}$ in $\mathrm{HBV}^{+}$DRibbles-immunized mice were greatly reduced as compared to both $\mathrm{HBsAg}$ vaccinated mice and control mice, and no statistical difference was found between HBsAg vaccinated mice and the control mice (Figure 4E). We found that the levels of serum $\mathrm{HBsAg}$ in $\mathrm{HBV}^{+}$DRibbles immunized mice were significantly lower than that of control mice without vaccination, but much higher than that of HBsAg immunized mice (Figure 4F). Detection of anti-HBsAg antibody in serum from immunized mice showed that HBsAg vaccination induced significantly higher levels of anti-HBs compared with $\mathrm{HBV}^{+}$DRibbles vaccination (Additional file 1: Figure S1A). Serum anti-HBsAg antibody was detected only in two of six mice received $\mathrm{HBV}^{+}$DRibbles immunization. Most importantly, HBV DNA copy number in the sera (Figure 4G) and percentage of $\mathrm{HBcAg}^{+}$hepatocytes in the liver tissues (Figure $4 \mathrm{H}$ ) in $\mathrm{HBV}^{+}$DRibbles-immunized mice were greatly reduced as compared to control mice received either no vaccine or HBsAg vaccine. In addition, sera ALT and AST levels were determined and appeared not to be influenced by the vaccinations (Additional file 1 : Figure $\mathrm{S} 1 \mathrm{~B}, \mathrm{C}$ ) and the livers from $\mathrm{HBV}^{+}$DRibbles vaccinated mice showed normal architecture and a mild

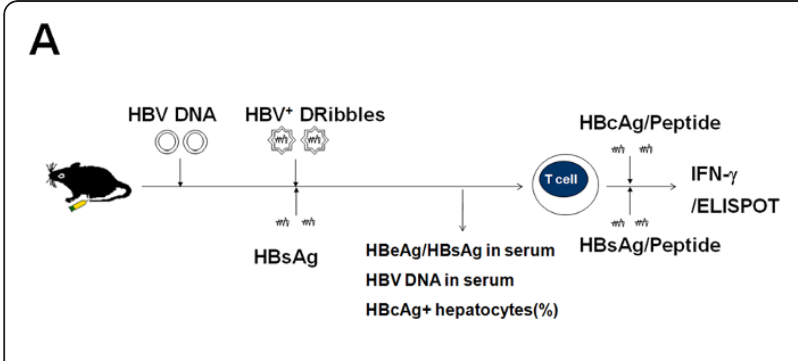

C

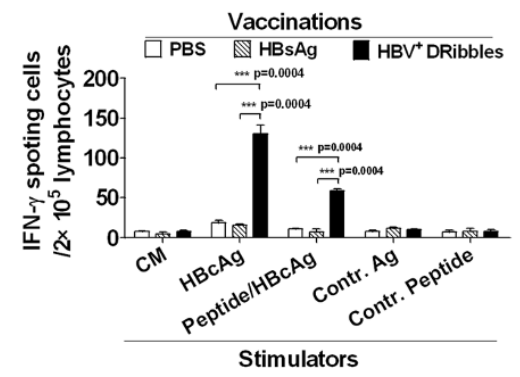

$\mathbf{F}$

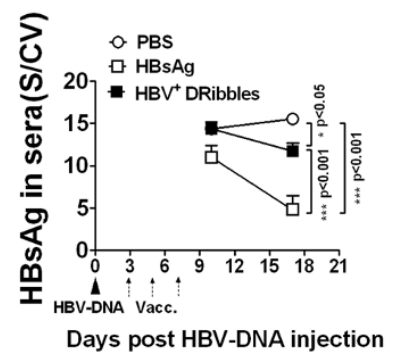

B

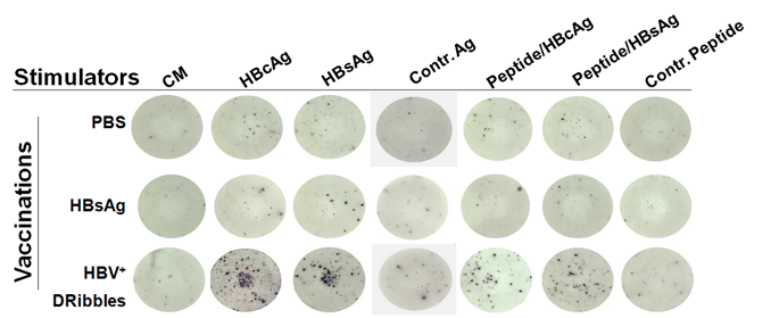

E

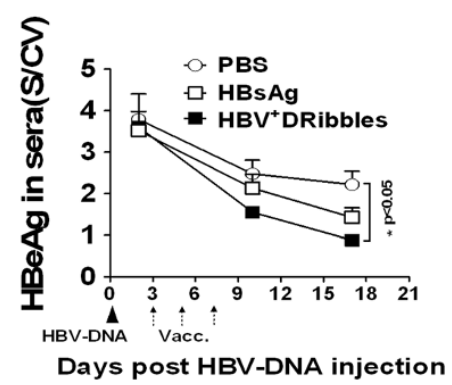

H

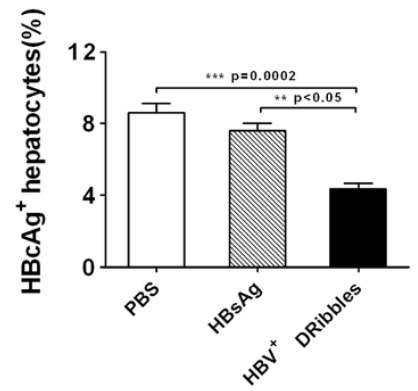

Figure 4 Therapeutic efficacy of $\mathbf{H B V}^{+}$DRibbles vaccine. The schematic diagram outlines the experiment protocol (A). Lymphocytes from the acute HBV-infected mice received $\mathrm{HBV}^{+}$DRibbles or HBsAg or PBS were isolated and re-stimulated with $\mathrm{HBV}$ antigens or peptides and the number of IFN- $\gamma$ producing cells in $2 \times 10^{5}$ lymphocytes was detected as described $(n=3)(\mathbf{B}-\mathbf{D})$. Serum HBeAg (E), HBsAg (F), HBV DNA copy number (G) and the percentage of $\mathrm{HBCAg}^{+}$hepatocytes $(\mathbf{H})$ of immunized mice or control mice were measured as mentioned above $(n=6)$. These experiments were repeated three times. 
inflammatory responses (Additional file 1: Figure S1D). Thus far, our studies indicated that $\mathrm{HBV}^{+}$DRibbles were more effectively than $\mathrm{HBsAg}$, at eliciting therapeutic cell-mediated immune responses in an acute HBV infection mouse model established by hydrodynamic injection of HBV plasmid DNA and did not cause obvious liver damage.
DRibbles induced therapeutic T cells and break tolerance in $\mathrm{HBsAg}$ tolerant mice

Next, we investigated whether $\mathrm{HBV}^{+}$DRibbles immunization could induce therapeutic immunity and break tolerance in a HBV tolerant mouse model. HBsAg tolerant mice were established by hydrodynamic injection of $\mathrm{HBV}$ DNA as described [18] (Additional file 2: Figure S2A).
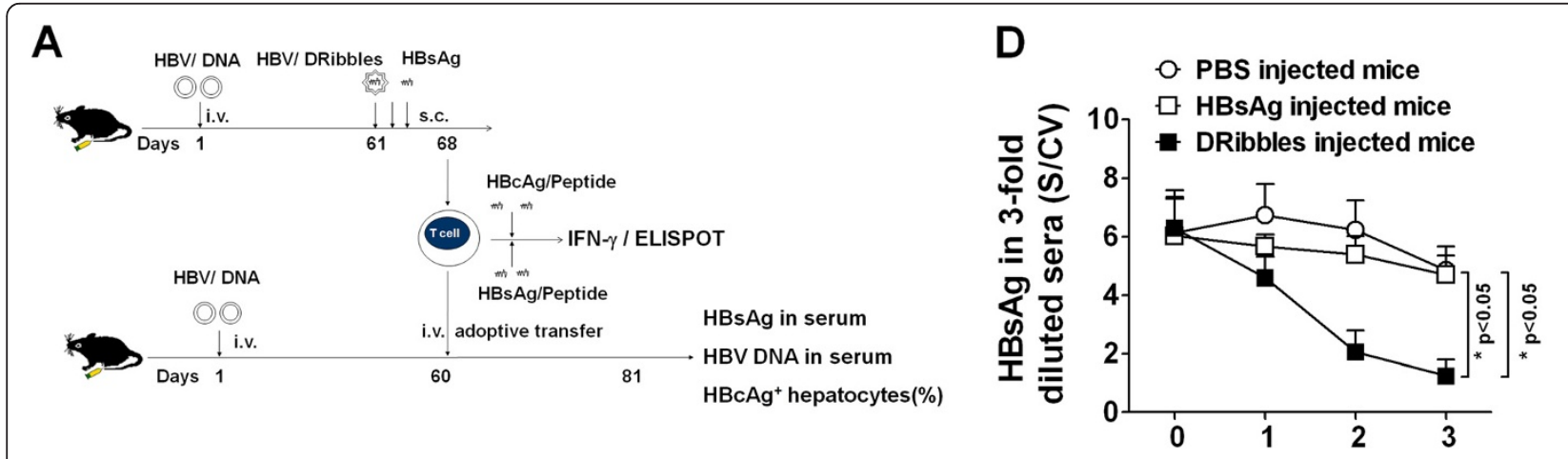

Weeks after i.v. adoptive transfer
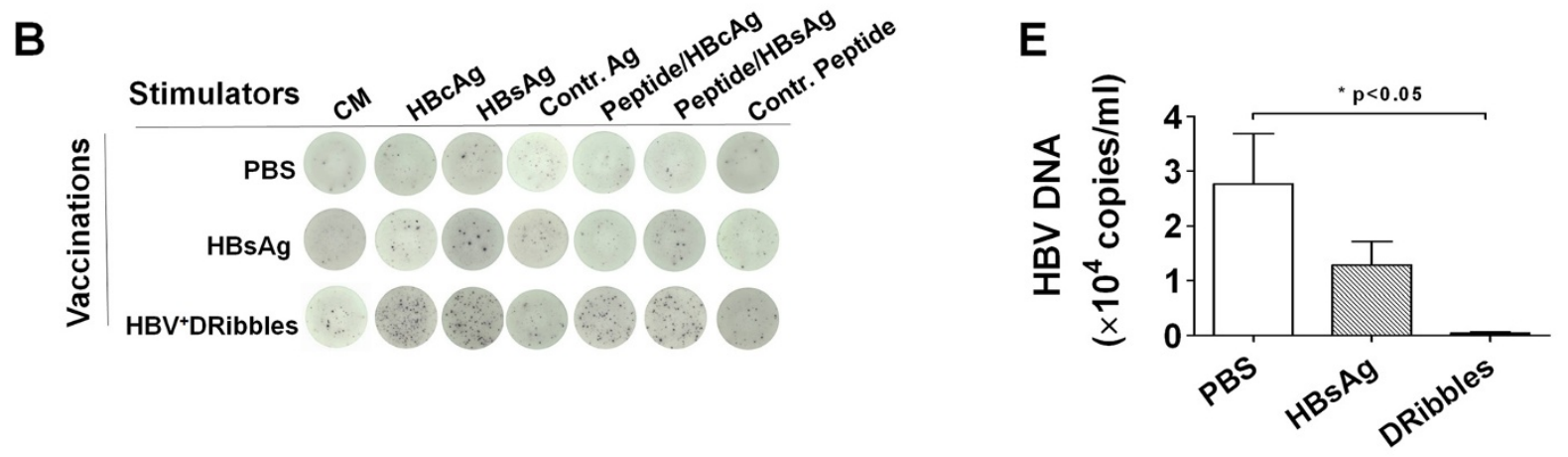

C
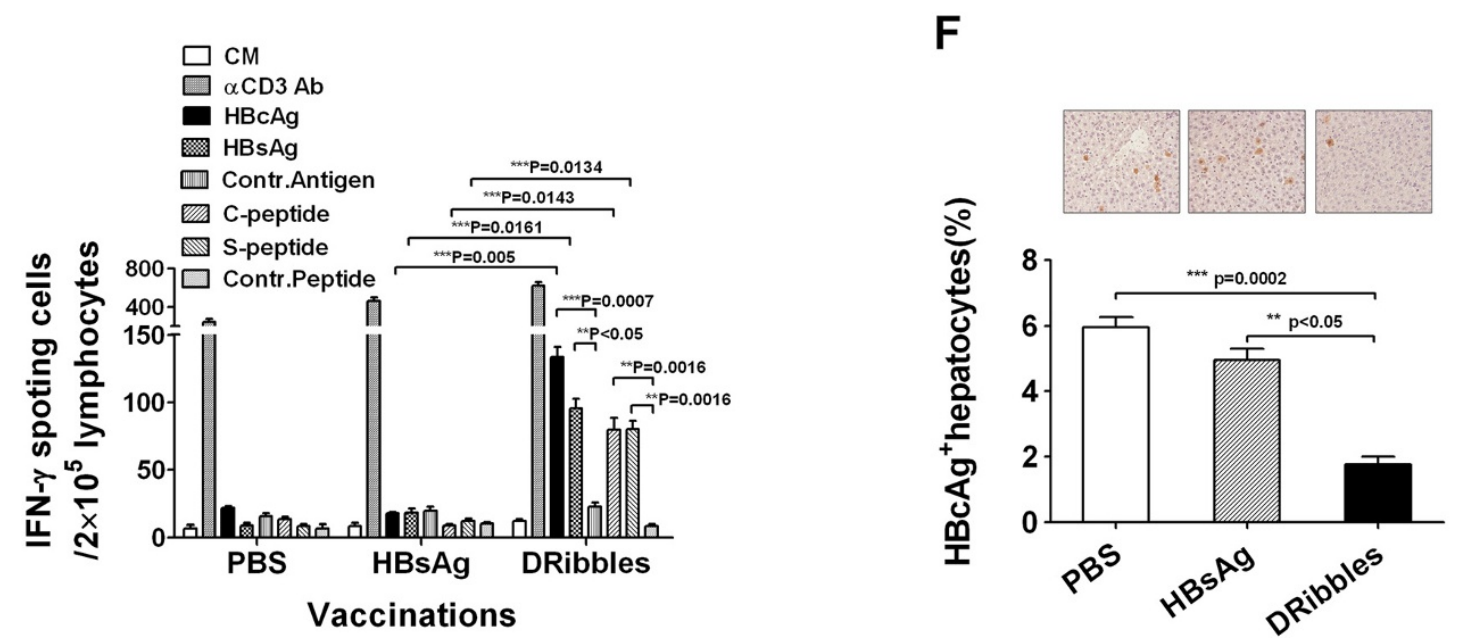

Figure $\mathbf{5}$ Immunized lymphocytes transfer adoptive immunity against HBV. The schematic diagram outlines the experiment protocol (A). $\mathrm{HBV}^{+}$DRibbles elicited IFN- $y$ producing cells in $2 \times 10^{5}$ lymphocytes against multiple HBV antigens or peptides $(\mathrm{n}=3)(\mathbf{B}, \mathbf{C})$. A total of $1 \times 10^{8}$ lymphocytes were adoptively transferred intravenously into each of the new 'HBV tolerant' mouse. At day 7, 14 and 21 after adoptive transfer, serum samples were collected for detection of HBsAg (D), HBV DNA copy number (E). The liver tissues were harvested on day 21 and HBCAg+ hepatocytes were determined as described $(n=4)(F)$. These experiments were repeated three times with comparable results. 
Two months after DNA injection, mice that are HBsAg positive were inoculated with $\mathrm{HBV}^{+}$DRibbles or HBsAg or PBS. Seven days after first immunization, lymphocytes were harvested and re-stimulated by HBV antigens and peptides (Figure 5A). The data showed that $\mathrm{HBV}^{+}$ DRibbles, but not HBsAg, induced HBV-specific IFN- $\gamma$ spot-forming cells when re-stimulated ex vivo with recombinant $\mathrm{HBsAg}$ or $\mathrm{HBcAg}$ proteins or MHC I binding peptides derived from these antigens (Figure 5B,C). Since the level of antibody response in DRibbles-vaccinated mice in the acute 'HBV infected' mouse model was very low, we decided to examine whether immune cells rather than serum conferred the control of HBV replication using an adoptive transfer model. To that end, immunized lymphocytes harvested from spleens and lymph nodes of immunized mice were adoptively transferred to a new set of HBsAg tolerant mice that received HBV DNA injection 60 days before. The levels of serum HBsAg, HBV DNA (Figure 5D,E) were markedly decreased and $\mathrm{HBcAg}^{+}$ hepatic cells were greatly reduced in $\mathrm{HBsAg}$ tolerant mice after adoptive transfer of lymphocytes from $\mathrm{HBV}^{+}$DRibbles vaccinated mice (Figure 5F). In contrast, the mice received lymphocytes from $\mathrm{HBsAg}$ vaccinated mice did not exhibit any measurable effect. Interestingly, anti-HBsAg antibodies were detected in mice received lymphocytes from DRibbles, but not PBS and HBsAg immunized mice (Additional file 2: Figure S2B). Furthermore, the serum ALT and AST levels in the mice received lymphocytes from $\mathrm{HBV}^{+}$DRibbles immunized mice were similar to that of received lymphocytes from non-immunized control mice (Additional file 3: Figure S3A,B) and the livers of the mice receiving $\mathrm{HBV}^{+}$DRibbles-treated lymphocytes showed normal architecture with a mild inflammatory infiltrates (Additional file 3: Figure S3C). The results indicated that $\mathrm{HBV}^{+}$DRibbles were able to reverse the tolerance to HBsAg and induce therapeutic $\mathrm{T}$ cells, and these HBV-specific $\mathrm{T}$ cells adoptively transferred into HBsAg tolerant mice did not cause severe liver damage.

\section{Discussion}

Previously, others and we demonstrated that autophagy of antigen donor cells plays a critical role in the crosspresentation of tumor associated antigens or viral antigens [12-16]. In this study, we investigated whether multiple HBV antigens could be accumulated in DRibbles by treatment of HBV expressing cells with various agents modulating proteasome function and autophagy mediated protein degradation [13-16]. In addition to the accumulation of HBV antigens, DRibbles also contained specific ligands and 'build-in adjuvant' could stimulate specific subsets of DCs to efficiently cross-present antigens. It is likely that membrane-structured DRibbles might include innate adjuvant activity for activation of innate and induction of antigen-specific $\mathrm{CD} 8^{+} \mathrm{T}$ cell response [14].
The development of candidate therapeutic vaccines for patients with chronic HBV infection is greatly hampered by the lack of clinical relevant mouse models. Fortunately, when HBV DNA is artificially introduced into mouse hepatocytes, HBV expression and replication can be established. Different methodology has been exploited to introduce HBV genome into adult murine hepatocytes [18,22-24]. Hydrodynamic injection of plasmid DNA typically results in about $10 \%$ of HBV-expressing hepatocytes, long-term HBV expression and immunological tolerance similar to chronic human HBV carriers $[18,23]$. Hydrodynamic injection of HBV DNA of mice is proven to be a good murine model for studies of HBV replication and immune responses. Here, we employed this model to develop a novel HBV therapeutic vaccine based on autophagosomes derived from HBV expressing hepatoma cells.

The $\mathrm{HBV}^{+}$DRibbles produced from a HBV expressing cell line were effective as a prophylactic vaccine or a therapeutic vaccine to treat mice with established HBV replication. Our results showed that $\mathrm{HBV}^{+}$DRibbles could prime both $\mathrm{HBsAg}$ and $\mathrm{HBcAg}$-specific immune responses and the IFN- $\gamma$ producing and $\mathrm{CD}^{+}{ }^{+} \mathrm{T}$ cells played dominant roles in the HBV clearance. It is previously reported that an impaired HBcAg-specific immunity is the major cause for HBV persistence after the hydrodynamic injection of HBV DNA [18]. HBcAg-specific immunity plays a critical role in the clearance of HBV and HBV antigenharboring hepatocytes $[25,26]$. As expected, $\mathrm{HBV}^{+}$DRibbles was able to reduce HBV replication in vivo. Whether $\mathrm{HBV}^{+}$DRibbles could also induce immune responses to other $\mathrm{HBV}$ antigens, such as $\mathrm{X}$ protein and HBV polymerase remains to be determined. The HBxAg is of particularly relevant antigen as it is required for productive $\mathrm{HBV}$ infection and replication [27]. HBxAg is a short-lived protein and rapidly degraded by proteasomes [28] and X-protein specific $\mathrm{T}$ cells are less likely impaired or exhausted in patients with chronic HBV infection.

Previous studies have demonstrated that both $\mathrm{CD} 4^{+} \mathrm{T}$ cells and $\mathrm{CD}^{+} \mathrm{T}$ cells are required for elimination of HBV from the liver during natural infection $[29,30]$. As helper $\mathrm{T}$ cells for both $\mathrm{B}$-cell and CTL responses against $\mathrm{HBV}, \mathrm{CD}^{+} \mathrm{T}$ cells serve as master regulators of the adaptive immune response to HBV. B-cells produce critical neutralization antibodies that prevent viral entry and $\mathrm{CD}^{+} \mathrm{T}$ cells are the key cellular effectors mediating HBV clearance by killing of HBV-infected hepatocytes. We found that HBV clearance in our model primarily depended on $\mathrm{CD}^{+} \mathrm{T}$ cells and $\mathrm{CD} 4^{+} \mathrm{T}$ cells was less important. The predominant dependence on $\mathrm{CD}^{+} \mathrm{T}$ cells is probably because hydrodynamic injection of HBV DNA effectively bypassed the viral entry step. However, we did not examine whether $\mathrm{HBV}^{+}$DRibbles could activate other innate immune components such as NK and NKT cells, as their contributions in the induction 
of specific anti-HBV immune responses and anti-HBV efficacy could not be ignored [31-33].

It is known that strong, multi-antigen specific, HBVspecific $\mathrm{T}$ cell responses in particular mediated by $\mathrm{CD} 8^{+}$ cells are correlated with HBV control and resolution $[29,30]$ and the neutralization antibodies could be critical important acting together with CTL to effective control and eliminate chronic HBV infection. During treatment of acute 'HBV infection' of our mouse model, $\mathrm{HBV}^{+}$ DRibbles vaccine was capable of eliciting strong and multi-specific $\mathrm{T}$ cell responses. Compared to $\mathrm{HBV}^{+}$DRibbles vaccination, $\mathrm{HBsAg}$ immunization could not generate $\mathrm{HBcAg}$ - and HBsAg-specific and peptides-specific cell response; however, it was able to induce humoral response. Interestingly, some of the $\mathrm{HBV}^{+}$DRibbles treated mice did produce anti-HBsAg antibodies, although the mean level was lower than that induced by HBsAg at the indicated time points. Importantly, when lymphocytes from immunized HBV tolerant mice adoptively transferred into new set of tolerant mice, the suppression of HBV DNA replication and the clearance of $\mathrm{HBcAg}^{+}$hepatocytes were only detected in $\mathrm{HBV}^{+}$DRibbles vaccinated group. Also, antiHBsAg antibody response could be induced in some of the tolerant mice after adoptively transferred of lymphocytes from $\mathrm{HBV}^{+}$DRibbles vaccinated mice. It is consistent with the notion that $\mathrm{HBcAg}$-specific $\mathrm{T}$ cells support the antiHBsAg antibody response [18]. The anti-HBsAg antibodies could also contribute to the neutralization of serum HBsAg, and the virus control and elimination of HBV infected cells required $\mathrm{HBcAg}$-specific $\mathrm{T}$ cells.

$\alpha-\mathrm{Al}_{2} \mathrm{O}_{3}$ nanoparticles, in contrast to traditional Alum adjuvant, are capable to deliver antigen for very efficient priming of CTLs and capable of boosting the anti-tumor efficacy of tumor-derived autophagosomes [19]. Our data demonstrated that $\mathrm{HBV}^{+}$DRibbles mixed with $\alpha-\mathrm{Al}_{2} \mathrm{O}_{3}$ nanoparticles could elicit an endogenous $\mathrm{T}$-cell response capable of eliminating established 'HBV infection'. The results suggested that $\mathrm{HBV}^{+}$DRibbles vaccine together with potent adjuvant was capable to elicit therapeutic immune response and overcome HBV tolerance in our mouse model. The recent identification of HBV receptor makes it possible to generate authentic mouse model for chronic HBV infection [34].

Furthermore, DRibbles vaccine strategy was developed for cancer patients with terminal diseases [13-16], their safety and efficacy are tested currently in phase I and II clinical trials. A more stringent requirement for safety needed to be taken into consideration if DRibbles derived from a hepatocellular cell line will be tested in chronically HBV-infected humans. DRibbles isolated from cell line will unavoidably compose of cellular proteins in addition to HBV antigens. We did not observe cross-reactivity with normal cells when mice were vaccinated with DRibbles derived from cancer cells or cultured normal kidney cells and long term survival mice did not suffer noticeable autoimmune diseases in preclinical studies (unpublished data), but the potential long-term adverse effects of DRibbles vaccine in cancer patients are not known yet. Because of the high probability of developing $\mathrm{HCC}$ in patients with chronic HBV infection, the potential benefit of protection against $\mathrm{HCC}$ induced by $\mathrm{HBV}^{+}$DRibbles derived from hepatocellular carcinoma cell line could outweigh the minimal risk of increased autoimmunity.

\section{Conclusions}

Our results indicate that autophagosome-based vaccine could induce multifaceted immune responses and target T-cell mediated immune responses to many antigens of pathogens, which are not efficiently elicited or rendered tolerant during the natural course of infections. Thus, our findings have important implications for the development of therapeutic vaccines for the treatment of chronic infections of HBV or other viruses.

\section{Additional files}

Additional file 1: Figure S1. Humoral response was induced in acute HBV infection. The same experiment protocol was performed as Figure 4. Serum samples were collected at day 14 after vaccination and anti-HBsAg antibody was detected by ELISA (A). Serum ALT and AST levels were measured on automated clinical chemistry analyzer at indicated time points $(\mathbf{B}, \mathbf{C})$. The liver sections were stained with hematoxylin-eosin at day 14 after vaccination $(\times 400)(n=6)(D)$.

Additional file 2: Figure S2. Tolerance toward HBsAg in HBV carrier mice. Serum anti-HBsAg antibody in HBV carrier $(n=4)$ or naive C57BL/6 $(n=4)$ mice after immunization with HBsAg vaccine (60 days after hydrodynamic injection of PAAV/HBV1.2 or PBS, the same protocol of HBsAg vaccination as above) was determined by ELISA at day 14 after vaccination (A). Humoral response was detected in chronic HBV infection. The same experiment protocol was performed as Figure 5. Serum samples were collected at day 21 after adoptive transfer and anti-HBsAg antibody was assayed by ELISA $(n=4)(B)$.

Additional file 3: Figure S3. Serum ALT and AST levels were measured on automated clinical chemistry analyzer at indicated time points $(\mathbf{A}, \mathbf{B})$ The liver sections were stained with hematoxylin-Eosin at day 21 after adoptive transfer $(\times 400)(n=4)(C)$.

\section{Abbreviations}

DRiPs: Defective ribosomal products; DRibbles: Autophagosome-based vaccine; $\mathrm{HBV}^{+}$DRibbles: Autophagosome-based vaccine from HepG2.2.15 cells; HBV DRibbles: Autophagosome-based vaccine from HepG2 cells.

\section{Competing interests}

The authors declared that they have no competing interests.

\section{Authors' contributions}

MX, FF and LD carried out the experiments. MX drafted the manuscript. JYL, SS, PFY contributed reagents for performance of some studies. $\mathrm{CM}, \mathrm{HMH}$ and LXW analyzed data and interpreted results of analysis. HMH contributed to the critical editing and revision of the manuscript. WZ, HMH and LXW conceived of the study, and participated in its design and coordination. All authors have read and approved the final manuscript.

\section{Acknowledgments}

We thank Dr. Suyu Shu (Cleveland Clinic, USA) for his critical review of this manuscript. We thank Dr. Peijie Chen (National Taiwan University, Taiwan) for providing PAAV-HBV1.2 plasmid. 


\section{Financial support}

This project was funded by a grant from the National Natural Science Foundation of China No. 31370895,31170857 (Lixin Wang), 81373121 (Hong-ming Hu and Wei Zhao), and Providence Portland Medical Foundation (Hong-ming Hu).

\section{Author details}

${ }^{1}$ Department of Microbiology and Immunology, Medical School of Southeast University, Nanjing, Jiangsu, PR China. ${ }^{2}$ Cancer Research and Biotherapy Center, the Second Affiliated Hospital of Southeast University, Nanjing, Jiangsu, PR China. ${ }^{3}$ Laboratory of Cancer Immunobiology, Earle A. Chiles Research Institute, Providence Portland Medical Center, Portland, Oregon, USA

Received: 5 August 2014 Accepted: 11 December 2014

Published online: 20 December 2014

\section{References}

1. Wu W, Shi Y, Li S, Zhang Y, Liu Y, Wu Y, Chen Z: Blockade of Tim-3 signaling restores the virus-specific $\mathrm{CD} 8^{+} \mathrm{T}$-cell response in patients with chronic hepatitis B. Eur J Immunol 2012, 42:1180-1191.

2. Fontana RJ: Side effects of long-term oral antiviral therapy for hepatitis $B$. Hepatology 2009, 49:S185-S195.

3. Ghany MG, Doo EC: Antiviral resistance and hepatitis B therapy. Hepatology 2009, 49:S174-S184

4. Gish R, Jia JD, Locarnini S, Zoulim F: Selection of chronic hepatitis B therapy with high barrier to resistance. Lancet Infect Dis 2012, 12:341-353.

5. Dienstag J: Hepatitis B virus infection. N Engl J Med 2008, 359:1486-1500.

6. Vandepapelière P, Lau GK, Leroux-Roels G, Horsmans Y, Gane E, Tawandee T, Merican MI, Win KM, Trepo C, Cooksley G, Wettendorff M, Ferrari C: Therapeutic vaccination of chronic hepatitis $B$ patients with virus suppression by antiviral therapy: a randomized, controlled study of co-administration of $\mathrm{HBsAg} / \mathrm{ASO} 2$ candidate vaccine and lamivudine. Vaccine 2007, 25:8585-8597.

7. Xu DZ, Wang XY, Shen XL, Gong GZ, Ren H, Guo LM, Sun AM, Xu M, Li LJ, Guo XH, Zhen Z, Wang HF, Gong HY, Xu C, Jiang N, Pan C, Gong Z, Zhang JM, Shang J, Xu J, Xie Q, Wu TF, Huang WX, Li YG, Xu J, Yuan ZH, Wang B, Zhao K, Wen YM, YIC Efficacy Trial Study Team: Results of a phase III clinical trial with an $\mathrm{HBsAg-HBIG}$ immunogenic complex therapeutic vaccine for chronic hepatitis $B$ patients: experiences and findings. J Hepatol 2013, 59:450-456.

8. Cavenaugh JS, Awi D, Mendy M, Hill AV, Whittle H, McConkey SJ: Partially randomized, non-blinded trial of DNA and MVA therapeutic vaccines based on hepatitis $B$ virus surface protein for chronic HBV infection. PLoS One 2011, 6:e14626.

9. Protzer U, Maini MK, Knolle PA: Living in the liver: hepatic infections. Nat Rev Immunol 2012, 12:201-213.

10. Michel ML, Deng Q, Mancini-Bourgine M: Therapeutic vaccines and immune-based therapies for the treatment of chronic hepatitis $B$ : perspectives and challenges. J Hepatol 2011, 54:1286-1296.

11. Kutscher S, Bauer T, Dembek C, Sprinzl M, Protzer U: Design of therapeutic vaccines: hepatitis B as an example. Microb Biotechnol 2012, 5:270-582

12. Crotzer VL, Blum JS: Autophagy and its role in MHC-mediated antigen presentation. J Immunol 2009, 182:3335-3341

13. Li Y, Wang LX, Yang G, Hao F, Urba WJ, Hu HM: Efficient crosspresentation depends on autophagy in tumor cells. Cancer Res 2008 68:6889-6895.

14. Li Y, Wang LX, Pang P, Cui Z, Aung S, Haley D, Fox BA, Urba WJ, Hu HM: Tumor-derived autophagosome vaccine: mechanism of cross-presentation and therapeutic efficacy. Clin Cancer Res 2011, 17:7047-7057.

15. Li Y, Wang LX, Pang P, Twitty C, Fox BA, Aung S, Urba WJ, Hu HM: Crosspresentation of tumor associated antigens through tumor-derived autophagosomes. Autophagy 2009, 5:576-577.

16. Twitty CG, Jensen SM, Hu HM, Fox BA: Tumor-derived autophagosome vaccine: induction of cross-protective immune responses against short-lived proteins through a p62-dependent mechanism. Clin Cancer Res 2011, 17:6467-6481.

17. Sells MA, Chen ML, Acs G: Production of hepatitis B virus particles in HepG2 cells transfected with cloned hepatitis B virus DNA. Proc Natl Acad Sci U S A 1987, 84:1005-1009.

18. Huang LR, Wu HL, Chen PJ, Chen DS: An immunocompetent mouse model for the tolerance of human chronic hepatitis $B$ virus infection. Proc Natl Acad Sci U S A 2006, 103:17862-17867.
19. Li Y, Jiao J, Hu HM: Alpha-alumina nanoparticles induce efficient autophagy-dependent cross-presentation and potent antitumour response. Nat Nanotechnol 2011, 6:645-650.

20. Yoshimori T: Autophagy: a regulated bulk degradation process inside cells. Biochem Biophys Res Commun 2004, 313:453-458.

21. Kabeya Y, Mizushima N, Ueno T, Yamamoto A, Kirisako T, Noda T, Kominami E, Ohsumi Y, Yoshimori T: LC3, a mammalian homologue of yeast $A p g 8 p$, is localized in autophagosome membranes after processing. EMBO J 2000, 19:5720-5728.

22. Larkin J, Clayton M, Sun B, Perchonock CE, Morgan JL, Siracusa LD, Michaels FH, Feitelson MA: Hepatitis B virus transgenic mouse model of chronic liver disease. Nat Med 1999, 5:907-912.

23. Huang LR, Gäbel YA, Graf S, Arzberger S, Kurts C, Heikenwalder M, Knolle PA, Protzer U: Transfer of HBV genomes using low doses of adenovirus vectors leads to persistent infection in immune competent mice. Gastroenterology 2012, 142:1447-1450.e3.

24. Guidotti LG, Matzke B, Schaller H, Chisari FV: High-level hepatitis B virus replication in transgenic mice. J Virol 1995, 69:6158-6169.

25. Jung MC, Spengler U, Schraut W, Hoffmann R, Zachoval R, Eisenburg J, Eichenlaub D, Riethmüller G, Paumgartner G, Ziegler-Heitbrock HW, Will H, Pape GR. Hepatitis B virus antigen-specific T-cell activation in patients with acute and chronic hepatitis B. J Hepatol 1991, 13:310-317.

26. Ferrari C, Penna A, Bertoletti A, Valli A, Antoni AD, Giuberti T, Cavalli A, Petit $M A$, Fiaccadori F: Cellular immune response to hepatitis $B$ virus-encoded antigens in acute and chronic hepatitis B virus infection. J Immunol 1990, 145:3442-3449.

27. Lucifora J, Arzberger S, Durantel D, Belloni L, Strubin M, Levrero M, Zoulim F, Hantz O, Protzer U: Hepatitis B virus $X$ protein is essential to initiate and maintain virus replication after infection. J Hepatol 2011, 55:996-1003.

28. Kim JH, Sohn SY, Benedict Yen TS, Ahn BY: Ubiquitin-dependent and -independent proteasomal degradation of hepatitis $B$ virus $X$ protein. Biochem Biophys Res Commun 2008, 366:1036-1042.

29. Yang $\mathrm{PL}$, Althage $\mathrm{A}$, Chung J, Maier H, Wieland S, Isogawa M, Chisari FV: Immune effectors required for hepatitis B virus clearance. Proc Natl Acad Sci U S A 2010, 107:798-802.

30. Thimme R, Wieland S, Steiger C, Ghrayeb J, Reimann KA, Purcell RH, Chisari $\mathrm{FV}$ : $\mathrm{CD}^{+} \mathrm{T}$ cells mediate viral clearance and disease pathogenesis during acute hepatitis B virus infection. J Virol 2003, 77:68-76.

31. Zeissig S, Murata K, Sweet L, Publicover J, Hu Z, Kaser A, Bosse E, lqbal J, Hussain MM, Balschun K, Röcken C, Arlt A, Günther R, Hampe J, Schreiber S, Baron JL, Moody DB, Liang TJ, Blumberg RS: Hepatitis B virus-induced lipid alterations contribute to natural killer T cell-dependent protective immunity. Nat Med 2012, 18:1060-1068

32. Mondelli MU, Varchetta S, Oliviero B: Natural killer cells in viral hepatitis: facts and controversies. Eur J Clin Invest 2010, 40:851-863.

33. Fisicaro P, Valdatta C, Boni C, Massari M, Mori C, Zerbini A, Orlandini A, Sacchelli L, Missale G, Ferrari C: Early kinetics of innate and adaptive immune responses during hepatitis B virus infection. Gut 2009, 58:974-982.

34. Yan H, Zhong G, Xu G, He W, Jing Z, Gao Z, Huang Y, Qi Y, Peng B, Wang H, Fu L, Song M, Chen P, Gao W, Ren B, Sun Y, Cai T, Feng X, Sui J, Li W: Sodium taurocholate cotransporting polypeptide is a functional receptor for human hepatitis B and D virus. Elife 2012, 1:e00049.

\section{Submit your next manuscript to BioMed Central and take full advantage of:}

- Convenient online submission

- Thorough peer review

- No space constraints or color figure charges

- Immediate publication on acceptance

- Inclusion in PubMed, CAS, Scopus and Google Scholar

- Research which is freely available for redistribution 